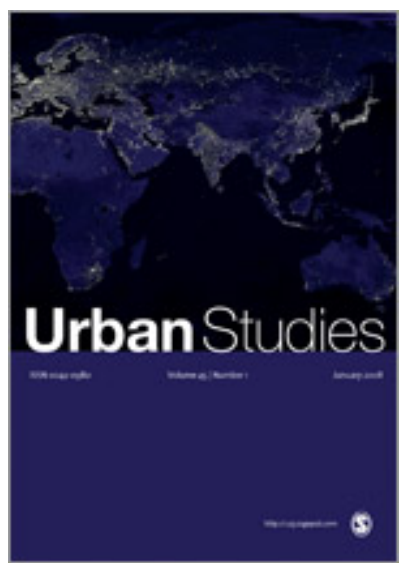

\title{
Data-Driven Governance, Smart Urbanism and Risk-Class Inequalities: Security and Social Credit in China
}

\begin{tabular}{|r|l|}
\hline Journal: & Urban Studies \\
\hline Manuscript ID & CUS-018-19-01.R2 \\
\hline Manuscript Type: & Special Issue \\
\hline $\begin{array}{r}\text { <b>Discipline: Please select a } \\
\text { keyword from the following } \\
\text { list that best describes the } \\
\text { discipline used in your paper.: }\end{array}$ & Geography \\
\hline $\begin{array}{r}\text { World Region: Please select } \\
\text { the region(s) that best reflect } \\
\text { the focus of your paper. }\end{array}$ & \\
$\begin{array}{r}\text { Names of individual countries, } \\
\text { cities \& economic groupings } \\
\text { should appear in the title } \\
\text { where appropriate.: }\end{array}$ & Asia \\
\hline $\begin{array}{r}\text { Major Topic: Please identify } \\
\text { up to } 5 \text { topics that best } \\
\text { identify the subject of your } \\
\text { article.: }\end{array}$ & Technology/Smart Cities, Class, Economic Processes, \\
\hline $\begin{array}{r}\text { You may add up to } 2 \text { further } \\
\text { relevant keywords of your } \\
\text { choosing below:: }\end{array}$ & data-driven governance, social credit \\
\hline
\end{tabular}

\section{SCHOLARONE Manuscripts}




\title{
Data-Driven Governance, Smart Urbanism and Risk-Class Inequalities: Security and Social Credit in China
}

\begin{abstract}
This paper contributes to the politicization of the smart urbanism and data-driven governance by making visible some of the potential inequalities emerging from these transitions through a provisional risk-class analysis. To pursue this analysis, it focuses on the case of smart urbanism and its associated process of data-driven governance in China, focusing specifically on the manner in which Chinese smart urbanism, in terms of its security measures, including widespread use of facial recognition, and the roll-out of social credit scoring, is affecting inequalities. This paper proposes risk-class analysis as a toolbox that can pose new questions in the search for what types of potential risks and inequalities emerging from smart urbanism and data-driven governance as is being rolled out in the Chinese context.
\end{abstract}

Keywords: actually persisting smart cities; data-driven governance; risk-class; Chinese smart cities; social credit

\section{Introduction}

The growing scope of big data technologies has extended the impact of algorithmic classifications beyond its initial paradigmatic case of credit ratings for the purpose of measuring the risk of late payment or default (Fourcade and Healy, 2013). With the emergence of data-driven and 'algorithmic' governance (Just and Latzer, 2017) and the associated development of smart urbanism (Greenfield, 2013; Townsend, 2013; Shelton, 
Zook and Wiig, 2015; Green, 2019), algorithmic classification is becoming fundamental to our overall social identity (Cheney-Lippold 2017). The inequalities emerging from these processes and how these processes can challenge conceptions of equal liberal citizenship have increasingly become an important point of contention (O'Neill, 2016; Eubanks, 2017). While there is some general agreement that increasing algorithmic governance is not leading to a fairer society, the targets of analysis differ in important ways. For O’Neill (2016) a lack of transparency and accountability of the algorithms making decisions is the fundamental problem. Eubanks (2017) instead highlights the problem of how the 'automating' of decision making processes removes human discretion and ultimately dumps risk on the already least advantaged. Datta and Odendaal (2019) in their discussion of 'Smart cities and the banality of power', focus on how smart city processes enable the normalisation of the violence involved with urban change.

This small selection of existing accounts of changes in power and inequality associated with algorithmic governance and smart urbanism are largely complementary, but raise a tangled network of issues. Shifting from governance via human discretion to big data collection and categories emerging from predictive analytics of algorithms does not limit power or inequality, but rather threatens to mask, or even extend, power. Algorithmic governance serves to displace attention from continued and intensified processes of suffering of the least advantaged. In light of these complementary accounts, this paper proposes a complementary approach with a framework that helps link the multitude of different transformations associated with algorithmic governance and smart urbanism. Our intention is to provide a heuristic to sketch and project the cumulative consequences of these transformations. 
Digital transformations have proceeded by what Beck (1992) calls 'fait accomplis', in which the role of the democratic debate is to approach a reality already reshaped by scientific and industry innovation and to ex post evaluate which particular innovations are too threatening. Most of the changes to finance, medicine, public debate, social interaction, and urban governance associated with the roll-out of networked digital technologies have emerged without public debate (Curran, 2018). Providing a general heuristic to better track the impacts of these transformations engages with overall questions surrounding the trajectory of the surveillance associated with big data, an increasingly networked social and material life, and the automation of ever more parts of social life.

The framework used here is that of 'risk-class' (Beck, 2013; Curran, 2013). It does not deny the importance of class analysis; rather risk-class analysis aims to integrate the analytical emphases of class analysis with the focus on risks as systematic objects of production and distribution, which modify relations of power and inequality. In this vein, this research aims to build on existing research that has sought to delineate key distributional impacts emerging from existing digital transformations (see as discussed further below, Citron and Pasquale (2014); Pasquale (2015); Eubanks, (2017); Mazzucato (2018); Zuboff (2019); and Fourcade and Kluttz 2020). Building on the distinction between actually existing and actually persisting smart cities, we discuss below key changes associated with the rise of smart urbanism and data-driven governance in China.

In the wake of American attempts to restrict the international adoption of Chinese Huawei's 5G network equipment, U.S. Vice President Pence attacked China's social credit program as an 'Orwellian system premised on controlling virtually every facet of human life' (quoted in Horsley, 2018). This attack built on exaggerated accounts of the current 
state of the social credit system, which tend to mistake intentions for accomplishments, but at the same time it points out crucial developments that are only part of a broad trend towards new forms of governance based on the collection and analysis of big data. These forms of governance are moving forward more quickly in China than anywhere else. In this paper, we examine these trends through risk-class, to map the distribution of new risks unevenly distributed among the population and the economy.

\section{Risk-Class}

Marx (1976) treated class as being based in unequal relations in production. Yet, with shifts in culture and the social sciences, from the latter part of the twentieth century there has been a shift away from class as social structuring based in production relations. Bourdieu's (1984) class analysis attempted to move beyond the dominance of the production paradigm. Critically reconstructing Weber's (1978) distinction of class and status, Bourdieu (1987, 2001) identified a series of social powers as 'capitals', including economic, cultural, and social, that can be accumulated and allow the advantaged to appropriate benefits within social fields. In this way, Bourdieu extended the scope of class power and of class conflict - even if it was not usually perceived under the aspect of class conflict - beyond the realm of production to reach to a more general theory of social power.

Fourcade and Healy (2013) build on other elements of Weber's critical engagement with Marx, focusing on Weber's (1978) insistence that class positions - even if fundamentally shaped by differential ownership and power relations within production emerge through diverse market positions. Decentring the focus on class as emerging from production relations, Fourcade and Healy (2013) identify how 'classification situations' as 
generated within market relations can in themselves not only reproduce, but intensify existing inequalities. They show how different classifications of credit scoring and differential access and pricing applied to individuals as consumers can have massive impacts on individuals' life-chances. Tying these processes to larger political economic contexts, they show how the neoliberal shift from collectivization to individualization as experienced in Anglo-American, liberal market economies has exhibited these processes in more extreme ways.

Yet, the growing importance of classification situations to individual life-chances is not just a product of changes in political economy, but also technological transformations in particular affordances in big data capture, storage, and analysis. There are significant preconditions in having systematic abilities to collect and collate information about a mass of individuals cheaply and to develop algorithmic processes to analyse and predict their future behaviour and hence classify individuals based on identified statistically significant connections between the different data points of masses of individuals. As MayerSchoenberg and Cukier (2013) argue, the transformation of social life into data and the corresponding analysis of this, which they call 'datafication', is a massive infrastructural project akin to the ambition of the building of the Roman aqueducts.

In this paper we use risk-class to analyse existing and potential inequalities emerging through transformations associated with smart urbanism and data-driven governance. This framework of risk-class captures systematic inequalities emerging from production and distribution of risks. Risk-class analysis builds on Beck's prescient idea that 'Risks like wealth are the object of distributions, and both constitute positions - risk positions and class positions respectively' (Beck, 1992: 26, emphases added). Specifically, 
'risk-class' identifies the intersection of class and risk - how they shape each other without being reducible to each other. It includes a toolbox of concepts to analyse the different relationships of risk and inequality: risk arbitrage, organised irresponsibility, structural risk position, private escape routes, relations of definition of risk, and risk illusion (see Beck, 1999; Haldane, Brennan, and Madouros, 2010; Curran, 2013). It identifies differential risk positions - individuals' respective benefit from the social production of risk and the damages they are exposed to from these socially produced risks.

Building on literatures on risk and inequality in finance (Lapavitsas 2009, 2013; Stiglitz 2010; Sherman, 2013) and in the environment (Davis 2001; Wisner et al. 2004; Mohai, Pellow, and Roberts 2009), risk-class analyses risks as objects of distribution that can be allocated to different groups based on their different social positions. Risk positions tend to be delineated with respect to a specific socially produced risk, such as the environment or finance (Curran, 2015, 2018b). Insofar as individuals tend to benefit overall across these risk domains, they occupy an advantaged risk position. While research on advantages across risk domains is still emerging, evidence shows that the most disadvantaged in one risk domain tend also to be disadvantaged across many risk domains. In this way, those who structurally cluster around these positions of disproportionately greater damage from the distribution of risk than benefit from the production of risk, are the least advantaged risk-classes. Those able to cumulatively benefit from risk more than they suffer damage from the distribution of risk can be said to constitute an elite-risk-class (Curran, 2015).

While class analysis continues to be the dominant modality for addressing inequalities, risk-class addresses limitations in class analysis. In particular, the production 
and systematic unequal distribution of goods continues to be the dominant analytical prism of class analysis. Yet, this retains the assumption of the potential for rational control which is at the core of Marx's account of the transition from capitalism to socialism - that production would grow so much that problems of scarcity could be overcome (Marx, 1991; see also Catton and Dunlap, 1978). Neglecting Weber's darker picture of the unintended consequences associated with modernity (Weber 2002), class analysis primarily focuses on the systematic production and distribution of objects that individuals will benefit from possessing.

In viewing class analysis as focusing on the unequal distribution of 'goods' (that is, social benefits, rather than just material goods) and how different social powers enable some groups to appropriate these goods, this paper builds on Savage, Warde, and Devine's (2005) insights into class from the CARs approach. They argue that class theory, including Bourdieusian, Marxist, and Weberian, has increasingly come to revolve around a framework in which differentials in Capitals, Assets, or Resources (CARs) are used to explain inequalities (Savage, Warde, and Devine 2005: 31-2). In light of this construal of class relations as based on differentials in CARs, Bourdieu's account of 'capitals' identifies the advantages and powers that emerge from these differentials within different parts of the 'social space'. Likewise, Marxist accounts of class identifies the unequal economic and social relationships based upon differentials of possession of the means of production, that is, the social relations of production within a given mode of production. And again, Weber's concept of class relations, based in differentials in 'market situations', can be conceived of as the powers emerging from differential economic resources within market relations (see Savage, Warde, and Devine, 2005). In this way, despite its many insights, 
class analysis neglects Beck's insight that 'In advanced modernity the social production of wealth is systematically accompanied by the social production of risks' (Beck, 1992: 19, original emphasis). While not seeking to dissolve or subsume class analysis, risk-class analysis focuses on the ineliminable connection between production of goods and of bads. Risk-class analysis highlights the systematic production of risks associated with innovation, which elites and corporations have an incentive to force into the background and off the political and regulatory agenda.

Risk-class analysis, akin to class analysis, identifies larger transformations in social inequality and power from changes in the primary structures of the economy, technology, and politics. The purpose of this is political, to allow for greater contestation, and epistemological critique. Providing a framework through which the accumulation of a multitude of different risks and inequalities can be converted into a form for which a broader, more comprehensive account of the risk transformations is provided. As wealth is accumulated at the top, so risks are accumulated at the bottom. Conceptual frameworks that allow for visibility of these transformations help critiques of smart city strategies attain greater precision and range in order to think through the justice implications of the projects.

Risk-class analysis addresses the problem of innovation and economic and social transformations by not only being backward-facing, but also forward-facing. Distributional transformations that have already occurred in income and wealth are admittedly a useful guide to future inequalities, but risk-class analysis integrates the future dimension of risk, taking into account the respective production of vulnerability for some and security for others. Insofar as smart urbanism creates massive privacy risks (Kitchin, 2016; Green, 2019), risk-class analysis integrates differential benefits (to digital innovators) and risks 
(especially to vulnerable citizens) into analysis of inequalities even if the risks never manifest in damages. By integrating differential levels of vulnerability and security riskclass analysis takes directly into account power differentials and their impact on the trajectories of innovation in a way that is much more difficult for accounts of class analysis locked into the paradigm of the production and distribution of goods.

Redistribution of risk is at the heart of changes in security and digitally networked control of the city. ${ }^{1}$ In this way, the indeterminate articulation in practice of the smart city exists more in the 'space of risks', than in the determinate space of redistribution of income or other components of life-chances. An ex post analysis of smart urbanism will be possible as it becomes less programmatic and more actual; however, given the nature of technological lock-in, this may already be too late. By analysing the trends within smart urbanism in terms of risk differentials and uneven benefits emerging from new risks, we can develop a novel prism through which to tackle inequalities in this emerging future.

\section{From smart cities to big data based (urban) governance}

There are two distinct ways of conducting research about smart cities. The first is to restrict oneself to the content and conceptualization of discourses and projects explicitly labelled as smart cities, and then discussing best practices or critiquing them. This is the dominant trend within the smart city studies. The second approach, adopted here, is to begin with a broad conceptualization of what a smart city is, and examine activities and discussions that pertain to that definition or looser understanding. This approach has challenges, most fundamentally that the definition of a smart city is contested (Albino et al., 2015, Vanolo, 2014). Simply relying on the sophistication or density of sensors and 
technology has limitations, because the social impacts of technology cannot be read off the number and sophistication of smart technologies. For our purposes here, though, it is precisely the nature of the technology that serves most usefully for our broader definition beyond explicit smart city strategies. Smart urbanism and the associated process of datadriven (urban) governance involve three key aspects that differentiate them from previous forms of urban governance: the collection of big data; the use of proprietary algorithms to analyze the data; and the 'real-time' use of the data to manage the urban environment (see Kitchin, 2014; Tang, 2015). Generally, but particularly in China, this phenomenon of datadriven governance sprawls beyond official smart city plans, resulting in distinct configurations of actually existing smart cities (Shelton et al. 2015), as opposed to those virtually existent in official plans. While this disjunction between plan and reality may result in empty stage sets or Potemkin villages, under Chinese conditions it can also lead to smartification that goes more rapidly and in directions those attuned only to official strategies may not be inclined to look.

Smart cities are perhaps the field in which the dangers of Eurocentric urbanism are most clearly revealed. We pay considerable attention in this paper to rapid growth of datadriven governance in Chinese cities, as they no longer lag behind the West in developing these cutting edge technologies, and are farther ahead in actually deploying them in urban management. Provincializing smart city research shows those of us in the global North our possible futures, reversing how colonial and postcolonial cities have more commonly been shown their paths to their futures by the presents of their colonizers (Chakrabarty 1992, Smart and Curran, in press). In both situations, there is also the prospect of learning before launching into mimetic duplication of others' mistakes. 
While recent growth in research on smart citizens rather than just smart cities (Cardullo and Kitchin, 2019, Datta 2018) is significant and politically useful, we see a tendency in much of this kind of research to focus on pilot projects, especially counter pilot projects by activists to demonstrate alternatives more compatible with social justice and local democracy. Yet, there are reasons to presume that most will be ephemeral. The trends among the tech giants are clearly towards oligopoly and standardization of platforms (cf. Cowley and Caprotti, 2019). So local pilot projects, while 'actually existing' (Shelton et al., 2015) may be unlikely to be actually persisting or influential in future directions taken by data-driven urban governance. What is happening in China, however, should not be neglected, because smart cities with Chinese characteristics are being governed in ways that are producing the world's biggest data pools, allowing the training of what will likely become the most powerful forms of deep machine learning. The urban governance oligopolist of the future may be Alibaba rather than Google, IBM, or Microsoft.

While smart cities attract considerable attention from urban planners and researchers, they are best conceived of as a subset of a broader phenomenon, the collection, analysis and use of big data for new (or intensification of existing) approaches to governance. This is happening at all scales from localities (Gardner and Hespanhol, 2018) to nations to global collaborations (e.g. initiatives to control tax evasion). While in Europe and North America, the city has perhaps been the most apparent arena of activity, in China the central party-state is more influential, conditioning municipal level initiatives in crucial ways. The result is distinct approaches to data-based governance, which may be worldleading due to the facilitation of rapid development of AI by massive collection and analysis of data (Lee 2018). We discuss these dynamics in the following sections. 


\section{The Political Economy of Urban innovation in China}

The distinctive nature of smart cities and big data-driven governance in China has to be seen in the context of its unique political economy. While central initiatives and plans are of great importance, how these work out in practice cannot be read off from the formal language of the initiatives (Smart 2018), as one of us has learned from field research in China periodically since 1987.

We have, unfortunately, been unable to do ethnographic research on smart city projects in China, because of political sensitivity and proprietary information, so our analysis is based largely on secondary literature, supplemented by discussions and observations during eight weeks in China in 2019 for lectures and research on other topics. In addition, past extended field research in China provides sensitivity to the context of project implementation.

The first issue that needs to be addressed is the widespread assumption that post1979 reform China can be understood as a variant of contemporary neoliberalism (Harvey, 2007). Harvey (1989) drew attention to how entrepreneurial urban governance has become generalized as part of the global urban condition. For China, neoliberal tools and practices have become increasingly important since 1979, and particularly since accession to the WTO in 2001. It is problematic to describe China as a neoliberal state, particularly under the current leadership of Xi Jinping. While some describe contemporary China as state capitalist, 'market Leninism' is more precise. Markets and capitalist practices are ubiquitous, in some ways less regulated than in the West (Smart and Smart, 2001), while Leninist techniques of political control are dominant, resurgent rather than declining. 
Fulong Wu argues that China has a mode of governance that uses market instruments but at the same time maintains state planning centrality (Wu, 2018: 1388). The global financial crisis in 2008 made state entrepreneurialism rely more on state-owned enterprises as an economic driver (Wu, 2018), so that the development processes significantly deviate from Western versions of urban entrepreneurialism (Wu 2020).

$\mathrm{Wu}$ argues that in contrast to passive planning responses to the ascendant market mechanism in the West:

Chinese planning is more proactive towards its growth agenda. This is another and different type of response to market orientation. ... the Chinese case may contribute to our understanding of different possibilities of governing urban transformation, within which neoliberalist planning may be one type among many. Greater orientation towards the market does not automatically lead to the reduction of planning. Rather, it strengthens the politics of using market instruments. (Wu, 2018: 1395)

Neoliberalism may have forced Western cities into servicing external actors to support growth, but the Chinese state maintains its key roles, with the center controlling local leaders, who act as entrepreneurs extracting rents from control over real estate development (Lin and Zhang, 2015; Zhang, 2014).

For Chinese smart cities, we cannot concentrate only on private corporations, but need to more fully incorporate the powerful party-state regime. The Chinese party-state generates different forms of 'urban growth machines' even while growth is still paramount for the system (He et al., 2018; Xue and Wu, 2015; Zhang, 2014). This system requires compliance with state priorities and targets, but rewards (politically acceptable) innovative 
approaches to meeting these targets (Chien and Woodworth, 2018). Party-state personnel reviews and growth targets create a strong impetus for rapid growth at all scales from neighborhood to nation.

\section{Smart Urbanism in China}

We go beyond explicit smart city projects to consider cognate governance projects under different labels (security, financial reform, and the social credit system) that collect massive amounts of data about the urban environment and citizens, used for governance and other purposes through big data analytics and other techniques. Such data-driven governance projects have to date had greater implications for the structuring of risk-class, so much of our analysis is devoted to them. We examine how these initiatives are changing the risk class position of various groups and categories in China, and suggest that differential distribution of risk should be a key consideration in adoption of new technologies and the algorithms and AI that are stitching them together into new forms of governance.

Immediate increases in risk are particularly placed on those who need to borrow money, those critical of the government, those more exposed to the consequences of public shaming, migrants, those working in the informal sector, and those in higher risk groups for criminality. The benefits for those with good social credit are already appearing: privileged access to travel, better interest rates, better insurance rates, etc.

The tight nexus between property developers and local governments means that many smart city projects are disguised urban renewal schemes, often displacing informal housing. Both big data collection and analysis and rival urban renewal and property development are motives. Yet, there is a risk that 'low-income individuals, less-educated 
groups, the elderly and others in need that do not have smart devices and/or do not know how to use them will be excluded' (China Academy of Information and Communications Technology, 2016: 201).

The National Urbanisation Plan (2014-2020) emphasized smart city development and encouraged not only technology and administration, but also 'meticulous social government' (Tan-Mullins et al. 2017: 2). Cowley et al. (2018) provide a catalogue of a wide diversity of projects incorporated into Wuhan's smart city projects. China is also increasingly structuring the global future of the internet: 'Whatever Washington does, the future of cyberspace will be much less American and much more Chinese' (Segal 2018:18).

Whether smart city projects actually make cities smarter is uncertain and contested (Sennett, 2012; Vanolo, 2014), but it is becoming clear that, particularly in countries with authoritarian governments and minimal protections for data privacy, such projects have become machines for accumulation of big data, and serve as 'test-beds' for new forms of machine learning and AI (Halpern, 2015). Smart city projects may improve the management of cities, such as optimizing traffic flows, but for corporations these benefits are means, not goals: to perfect $\mathrm{AI}$ and to mine the data needed to train profitable and exportable platforms.

The Hangzhou government launched a project called 'City Brain' with Alibaba Group in 2016. City Brain uses the ET AI technology of Alibaba Cloud to conduct realtime analysis of the city, automatically deploy public resources, and improve urban operations. First used in one district for transportation management, increasing traffic efficiency by $11 \%$ (People's Daily, 2017), implementation of City Brain is possible due to the project's connection to governmental databases. Alibaba is 'slurping up video feeds, 
social media data, traffic information and other data'. The stated goal was to improve life by letting AI use data to control aspects of urban life. It 'seems to have worked. The trial has been so successful that the company is now packaging the system for export to other places' (Revell, 2017: 7). Combined with China's vast number of highly capable video cameras (the largest array in the world), the system can index all video footage to be searched quickly. If police give City Brain a picture of a vehicle or pedestrian, the AI returns matches detailing where and when that vehicle has been in the city since the project began. This provides massive capabilities to locate those who defy court orders, or political dissidents.

Alibaba has begun to export the City Brain platform outside the mainland of China: to the Special Administrative Region of Macau in 2017, and to Malaysia in 2018 (Ho, 2018). Alibaba is working with 120,000 developers and 2,700 academic institutes and businesses from 77 countries and regions in a logistics project called Tianchi (Beall, 2018). This is part of what has become known as the 'digital Silk Road', part of China's worldchanging Belt and Road Initiative which is 'reshaping the geography of the Earth's biggest land mass' but having a major impact far beyond Eurasia (The Economist 2020:3). Only moving into clear global focus, geopolitical rivalry over the Belt and Road Initiative 'will in future play out more in the digital realm than in the world of commerce' (The Economist 2020:10), while 'many believe that China intends the digital Silk Road to be the main stage on which the BRI plays out in future. The question is whether the West will let it' (The Economist 2020:11).

What is central to the City Brain project is the ability to create a global platform. While the information it relies on is local, it is not used simply to improve the management 
of a particular locality, but to develop the AI program. Detailed knowledge of local context and history is no longer seen as the key factor in effective urban management, but something to be collected and easily transported from one locality to another, if the data collection hardware is sufficiently developed. If not, the corporation can make even more money by installing it as part of the smart city project. However, local needs remain diverse, and a transposable smart management system may divert resources from pressing requirements in that particular context. The tool's capabilities will drive the choice of solutions, whether optimal for local needs or not.

Despite City Brain's potential importance, the crucial ways in which high technology and big data analytics are changing the management of cities are largely happening outside official smart city plans, in areas such as financial technology and facial recognition technology. Fast adoption of fashionable urban models encourages the copying of models without critical consideration or open debate. This may result in empty plans, but it can also encourage outsourcing to access key technologies developed by corporations, whether state enterprise or private, or a hybrid form of both. The result is a distinct configuration of actually existing smart cities (Shelton et al., 2015), as opposed to those virtually existent in official plans. While disjunction between plan and reality may result in empty stage sets, under Chinese conditions it can also lead to smartification that goes more rapidly and in directions those attuned only to the official strategies may not notice.

While much key technology is the product of Western corporations, increasingly the cutting edge also involves Chinese corporations. Centrality of big data to machine learning forms of AI gives China a big advantage, because of the population size and much greater 
adoption of mobile shopping. In 2016 Chinese mobile payment transactions were US\$5.5 trillion, almost fifty times more than in the U.S.A., generating massive geo-specific data for Alibaba and Tencent (Larson, 2018). In 2017 China adopted a policy to become the world's 'primary AI innovation center' by 2030 and already spends more in the field than the U.S. (Larson, 2018:628). As importantly, China has few legal and political constraints on governmental and corporate use of personal information (Economist, 2018a).

China has built a massive facial recognition database that can identify a citizen within seconds. The project was launched by the Ministry of Public Security in 2015 (Chen, 2017). ${ }^{2}$ Some police are now equipped with database connected cameras that allow them to scan faces and identify suspects. Rollout of facial and automobile number plate recognition is particularly intense where the state fears separatist sentiments, such as Xinjiang in central Asia. Spending on internal security in Xinjiang (including re-education camps) grew five times from 2007 to 2016 , and then another $1000 \%$ by the end of 2017 to 59 billion yuan (Economist, 2018d). Nation-wide, China's surveillance technology market has been estimated at $\$ 120$ billion in 2018 (Economist, 2018e).

Surveillance is not new in the PRC, nor fully dependent on digital technology. Surveillance systems in China build on old paper file and document technologies that took modern form in the 1950s as the household registration system (Smart and Smart, 2001, Solinger, 1999). This originally prevented people from moving from their native place to other localities without permission. After economic reforms since 1979, movement became possible, but in most cases without formal transfer of household registration, creating a vast population of second-class citizens, over 200 million at present. They are easily removed when migrants are considered problems (for example, during the Beijing Olympics, 
intended to showcase a modern, clean, world-class city). However, avoiding detection is harder in a world of ubiquitous cameras, linked to biometric ID cards, and the world's most effective facial recognition system. This combination of bureaucracy and technology affords much greater control over everyday life, as can be seen in pilot projects.

Some urban management staff in Shenzhen use tablets to manage rental properties. Information for each household is collected, such as the room number, identity card, arrival date, length of residence, household composition, and lease conditions. Shenzhen started an information system to manage migrants and rental properties in 2004, investing 40 million yuan. By 2013, 10.2 million suites were recorded. ${ }^{3}$ In Guangzhou, control over rentals was deployed in one of the main areas of concentrations for Africans, and has pushed them into other districts. According to Yue Gong (2016:1000): 'In major cities and provinces, the surveillance is shifting from [hukou-based police management], which targets migrants' household identities, to spatial-oriented management targeting these migrants' rental housing'. Multiple local authorities combine their forces to 'shape panoptic spaces of rental housing while continuously developing various surveillance techniques in order to inspect, identify, and control migrants'. Four main techniques are 'partitioning, monitoring, digital entrance guarding, and local registration' (p. 1000).

In an informal settlement in Nanning, Guangxi Province, with many migrants without local household registration, the Public Security Bureau promotes a system in which $95 \%$ of rental units in the village have a real-name access control system. Residents access the building by using identity cards, residence permits, or biometric citizen cards. The entrance is equipped with high-definition cameras and networked alarms. To live there, migrants must register for a biometric card at the security office. After verification the 
information is sent to the community policing platform on police officers' mobile phones. ${ }^{4}$ Such systems are being intensified during the fight against Covid-19.

Next, we consider the social credit system, although analysis can be only preliminary. Since it has not yet rolled out at the national scale, its actual features and consequences will not be known for years.

\section{The Chinese Social Credit System}

Proposed by the State Council in 2007, the social credit system's aim was initially at companies and solidifying a socialist market economy with major food safety scandals and debt defaults, and inadequate data for conventional credit scoring. When launched nationally in 2014 (with an anticipated 2020 completion date), its goals had expanded: to assess the trustworthiness of Chinese citizens and companies in complying with legal rules, moral norms, and professional and ethical standards (Liang et al., 2018). There has been a great deal of media attention to this Chinese in-progress system, first engaging in considerable 'Big Brother is watching' hyperbole, and since castigating those who started paying attention to it early as misunderstanding (Horsley, 2018, Matsakis, 2019). The largest error has been presenting the social credit system as already operating at a national level, and the adoption of science fiction projections of what might happen.

Shazeda Ahmed (2018: 48) notes that the 'Core beliefs many observers outside of China hold about the system - that it feeds into a single numerical score, and that facial recognition-enabled cameras and other digital sensors are constantly updating a central government database that calculates these scores—are mistaken' (Ahmed 2018: 48). 
Another major problem is that reporting often confuses the social credit program with the credit scoring system developed by Sesame Credit (Horsley, 2018). It is possible that this would end up providing some of the technology for the national system, but this is still uncertain. In 2015 the People's Bank of China authorized eight companies, including Sesame Credit, to seek credit reporting licenses. None qualified, but in 2018 the bank licensed Baihang Credit with those eight companies as shareholders (Horsley, 2018). While not part of the social credit program yet, its incorporation is likely.

What is different in China is the 'scale of the data collected, the scope of its use and ... the apparent lack of a comprehensive legal system to protect personal data' (Chen and Cheung, 2017: 2). With inadequate protection for personal data China is 'an ideal social laboratory for big data experimentation, data intelligence and mass surveillance. Individuals risk being reduced to transparent selves before the state in this uneven battle. They are uncertain about what contributes to their social credit scores, how those scores are combined with the state system, and how their data is interpreted and used' (Chen and Cheung, 2017: 3). A comprehensive, nationwide platform aggregating all related data is planned to be mandatory by 2020 . The social credit system is currently a collection of blacklists, more than a dozen at the national level, and many more locally. Each list is based on offenses such as misbehavior on planes and trains, or failing to abide by a court judgment.

For those with a lower score, a 'rating may be risky.... the database includes a list of more than $6 \mathrm{~m}$ people who have defaulted on court fines, which has helped the courts catch up with more than $1.2 \mathrm{~m}$ defaulters' whose credit score plummeted (Economist, 2018c:10). China's blacklists have blocked people from taking 11.14 million flights and 
4.25 million high-speed train trips (Chan, 2018). Highlighting the spatial implications of the digital algorithmic representations of social trustworthiness (see also Dalton et al. 2020), the State Council guidelines stated that the SCS will 'allow the trustworthy to roam everywhere under heaven while making it hard for the discredited to take a single step' (Botsman, 2017).

In some localities, those who haven't complied with court orders have their ring tone replaced: callers receive a recorded message telling them the person is on a blacklist. Given the strength of shame as a social motivator in China, such shaming messages can be very effective. Even the government is suggesting that when people can access the social credit scores, it will affect dating and marriage patterns. The Shanghai government suggested in 2016 that 'filial piety be entered into the scoring system, assessed, for example, by the frequency with which an individual visited his or her parents and by whether an individual's parents had enough food' (Chen and Cheung 2017: 6). Reinforcement of traditional values by futuristic databases will create risks for those who do not conform to mainstream values, such as LBGTQ people or critics of government. China will probably have to rely on private tech companies with expertise in big data analytics to implement a national system, but state banks may be in the lead position. Alibaba, now listed on the New York Stock Exchange, introduced Sesame Credit in 2015 as an internal rating system based on the habits of Alipay users. Credit scores range from 350 to 950 points. Scores above 600 are considered creditworthy. Credit scores are based not only on their own lending and spending habits but on 'what the money in question is going towards and also on the lending and spending habits of their friends' (Chen and Cheung 2017: 9). Although some enjoy the convenience offered by Sesame Credit scoring 
(McDonald, 2019), many cannot afford to remain outside the system regardless of what they think of it. Furthermore, benefits and convenience to some mean sanctions and exclusion for others.

Local prototypes for the social credit system are already impacting non-Chinese individuals and companies, creating a clear risk-class exposed to regulatory changes. This includes not only those living in or doing business in China, but also those doing business with China, an ever-growing category in the context of the rise of the world's second largest economy. The system is 'already shaping the behaviour of foreign businesses in line with Chinese Communist party preferences'. Since January 2018, all companies with a Chinese business license must obtain a 'unified social credit code', through which the Chinese government keeps track of all businesses on its National Enterprise Credit Information Publicity System. This will apply to non-profits, NGOs, trade unions and social organisations from July 2018 (Munro, 2018). For countries and companies involved in China's 'One belt, one road' project to dramatically expand infrastructural linkages between China, Central Asia, Europe, the Middle East and Africa, the influences could be even greater (Mac Síthigh and Siems, 2019). Alibaba founder Jack Ma met with the Prime Minister of Canada in 2017 and urged the Canadian government to grant expedited visas for Chinese visitors by using the Sesame Credit rating platform (Liang et al. 2018).

China's emerging social credit system is neither a fantasy nor an all-seeing system of surveillance, but it is still important for what it might portend for the future, particularly if adopted elsewhere. Current government efforts are focused on integrating 'separated platforms into centralized data infrastructures. By doing so, the state hopes to modernize its surveillance system with key features promised by big data enabled innovations. It is in this 
sense that big data technology is being instrumentalized by the state, enabling the state authority to manage, monitor, predict, and govern each actor in its political, economic, and social domains' (Liang et al., 2018: 426). Mac Síthigh and Siems (2019: 29) ask whether it should be a model for other countries, arguing that in the form that seems to be developing it has advantages over subjective ranking systems (e.g. Uber), and that it 'should be studied in the West, not as a template or even a counter-model, but as illustrations of the implications of today's emphasis upon quantification and reputation across a range of domains'. As the technology matures, the social credit system will have a global impact. 'Science fiction' style projections of the possible futures that it might portend do have some value. After all, government programs tend towards mission creep: surveillance capacities that develop are likely to be used without powerful systems to prevent it. As Mastakis (2019) suggests, one of the bigger risks of the dystopic accounts of China's social credit system might be that it reassures us that what is happening in the West is much less threatening.

\section{Security and Social Credit and Risk-Class Inequalities}

'Smartness' as a description of a city renders opaque as much as it illuminates. Collection and analysis of big data and 'algorithmic' forms of governance that will manage the smart city raise important questions of power and inequality (Brauneis and Goodman, 2018). Algorithmic governance of social life through 'reputation systems' such as social credit in turn create winners and losers (Dai, 2018). With reputation systems, which reward and correspondingly punish behaviour, risks are being generated and unevenly distributed. In trying to solve fundamental problems of trust, reputation systems create risks for all, 
including those who have gained wealth through corruption and law-breaking, but the already class advantaged have greater power to ensure they keep a high credit score (see Dai, 2018). Chinese state reputation systems are in many ways an outgrowth and further extension of the logics of reputation systems and credit scoring systems that have increasing influence on governance in the Global North (Citron and Pasquale 2014; Eubanks, 2017; Dai, 2018; Brauneis and Goodman, 2018). As such, Chinese social credit programs potentially offer insight into a sped-up and involuntary version of the slower, 'quieter' revolution of a nominally voluntary, though increasingly necessary for social goods, type of reputation systems and credit scoring growing in the Global North (see also Hurley and Adebayo, 2016). .

The benefits of increased security measures and increasing employment of social credit to provide or deny access are targeted towards, or at least have the impact of, increasing the advantage of those with security and social legitimacy. Facial recognition software, increased surveillance and control over renters, and the systematic amalgamation of person information, like types of algorithmic policing increasingly occurring in the US (Eubanks, 2017), are not targeted at the advantaged, who already enjoy economic advantages and social legitimacy, except by providing enhanced services. Rather, the targets of measures are those who exist in informal, indeterminate legal zones, such as small businesses, migrants, squatters, or those who engage in small-scale criminality as a means of survival (see Wacquant, 2008). That is, these smart urban security measures are not directed to overcome the disadvantages and conditions of 'urban outcasts', but rather to further control them and deny them access to modes of living and even spaces that may 
disrupt the more advantaged and socially legitimate, thus intensifying risk-class inequalities.

Social credit illustrates the potential for data-driven governance to intensify and reify existing inequalities. Falling behind in different dimensions of what counts for one's social credit score will likewise further deny access to resources, social spaces, and social legitimacy, thus further intensifying the challenges in acquiring the means to achieve an adequate score. Similarly, for dissidents and other groups who do not fit into dominant ways of measuring social acceptability, the dangers of falling behind on a single score that aims to provide general 'legibility' (Scott, 1998) of the amount of trust that should be placed in a person's behaviour - creates massive risks for the already marginal and disadvantaged. Social credit is not simply a measure of laws that have been broken, but a fusing of measures based on laws and 'norms', heavily shaped by corporate, private interests in terms of what can justify blacklisting and what cannot. As such, the shortcircuiting of democracy and the public inherent in this process is clearly displayed. The ultimate components of the algorithm for social credit scores is still not clear, but the way that different social expectations are or are not encoded into a definite social credit score is of massive public importance, despite being removed from public debate or consultation. The logic of scores is not primarily to legally prevent people from doing things; rather high scores are an advantage in terms of enabling access to a variety of different goods and services. As a result, social credit exists in the nebulous space of de facto necessity to adequately function in society (Sen, 1993), but neither is it yet legally required nor is access to its provisions legally protected. The massive risks created for some groups, while others can rest secure of their advantages despite these massive transformations, fits with other 
theoretical treatments that emphasise the growing precaritisation of disadvantaged groups (Standing, 2013) and shows that risk is becoming a key source of contemporary inequality (Curran, 2016).

\section{Conclusion}

Data-driven governance and smart urbanism have the potential to generate new logics of governance and of inequality. In many ways, the massive amplification of complexity associated with the shift to big data and algorithmic governance associated with smart urbanism has made it more difficult to comprehend the full implications of these transformations (Gabrys 2014; Bridle 2018; Krivý 2018). In face of these challenges, new frameworks and understandings need to emerge to attempt to provisionally chart the power and inequality implications of smart urbanism and algorithmic governance. This has led to a plethora of different frameworks that have attempted to identify algorithmic harms associated with inequalities relating to differential visibility and invisibility (Tufecki 2015); the biases of big data 'automating inequality' (O’Neill 2016; Eubanks 2017; Couldry and Meijas 2019; Green, 2019), how data intermediaries are able to appropriate rents (Mazzucato 2018; Sadowski 2020), and how the emergence of surveillance capitalism is enabling new logics of commodification and control (Zuboff 2019). Building on emerging research on the political economy of risk, this paper proposes that employing risk-class analysis as a heuristic to sketch some of the larger distributions of power and inequality associated with smart urbanism and data-driven governance can help to provide another framework to organise and investigate these larger transformations. 
The transformation of inequalities is layered on top of already existing inequalities, intensifying many of these already existent inequalities. Security, mobility, flow, the speedup of what is permitted and the immobilization of what is not are core to discussions of optimization in smart urbanism (Alibaba Cloud, 2018; see also Botsman, 2017). As the discussion of security and social credit in China through the prism of risk-class illustrates, these technological governance changes are not 'neutral', but rather have the potential to intensify risk inequalities in powerful ways. The already advantaged in terms of security and social legitimacy can exercise greater control over flows of people, while the informal, marginal, disadvantaged and those who fall outside of socially dominant valuations can see their disadvantages multiplied as facial recognition and social credit allocate them to 'risky' categories. The potential for inequalities to multiply are significant in view of the emergence of this governance modality driven by big data, statistical categorization, and prediction based on algorithms, rather than democratically determined characteristics.

Theoretically, the paper firstly adds risk-class analysis as a prism to bring greater visibility to the inequalities emerging from changes associated with smart urbanism and data-driven governance. Secondly, it articulates the distinction between actually existing and actually persisting smart cities to understand existing transformations in smart urbanism, and, lastly, in an inversion of the view of the Global North as leading, this paper highlights the possibility of Chinese data-driven governance showing the Global North its potential future. Empirically, this paper uses these frames to speak to the political economy of urban innovation in China, the development of the 'digital Silk Road', and how smart urbanism and social credit in China are currently transforming existing risk inequalities. 
In developing this analysis, we have examined developments in the rapid growth of data-driven governance in Chinese cities. They are no longer lagging behind the West in developing these cutting edge technologies, and are much farther ahead in actually deploying them in urban management. Provincializing smart cities shows those of us in the global North our possible futures, in a reversal of the ways that colonial and postcolonial cities have more commonly been shown their paths to their futures by the presents of their colonizers (Chakrabarty, 1992, Curran and Smart in press). In both situations, there is also the prospect of learning before launching into mimetic duplication of others' mistakes.

As mentioned above, smart urbanism and data-driven governance are at an early stage where only tendencies, but not determinate outcomes, can be identified. Yet, given the powerful lock-in effects of platform technology used in big data analytics, it is difficult to reverse course when problems are found ex post. In this condition, thinking in terms of the 'space of risks' is crucial. While the ultimate effects of data-driven governance and smart urbanism are hard to specify, the trend of the distribution of risks are more identifiable. Those already enjoying security and social credit advantages occupy a riskclass in which they can securely enjoy these changes, knowing that the sharp edge of their effects will not fall on them. The marginal, poor, informal, at-risk groups on the other hand are the target of processes that have the potential to massively change their lives, making them the objects of ever more intensive surveillance and control. Moreover, standing behind these processes are the digital giants who doubly benefit by receiving free 'big data' to constantly improve their algorithms, while creating powerful relations of dependence of state authorities on proprietary algorithms that states use, but do not own. Massive valuations of the digital giants clearly show that the oligopolistic power that digital giants 
have is core to their business model and its promise of greater future profits (Mazzucato 2018). While risk-class analysis cannot by itself provide a comprehensive frame to unveil this future, it can make visible the massive transfers of advantages to one group and the massive dumping of risk on the already disadvantaged in these transitions. As such, this frame may aid in politicizing these undiscussed, undefended, but nevertheless massive redistributions at the heart of these evolving forms of governance and the everyday practices of urban life.

\section{Acknowledgement}

Thanks to Deborah Davis, Yonn Dierwechter, and Yawei Zhao for their helpful comments on this paper. We would also like to thank SSHRC [grant 435-2015-0339] for funding part of this research.

\section{References}

Ahmed S (2018) Credit Cities and the Limits of the Social Credit System. In AI, China, Russia, and the Global Order: Technological, Political, Global, and Creative Perspectives, 48-54. Strategic Multilayer Assessment Periodic Publication. https://nsiteam.com/social/wp-content/uploads/2019/01/AI-China-Russia-GlobalWP_FINAL_forcopying_Edited-EDITED.pdf\#page $=63$

Albino V, Umberto B, and Dangelico RM (2015) Smart cities: Definitions, dimensions, performance, and initiatives, Journal of Urban Technology 22(1): 3-21.

Alibaba Cloud (2018) ET City Brain. Available at: https://www.alibabacloud.com/et/city (accessed 20 June 2018). 
Beall A (2018) In China, Alibaba's data-hungry AI is controlling (and watching) cities. Available at: www.wired.co.uk/article/alibaba-city-brain-artificial-intelligencechina-kuala-lumpur (accessed 9 October 2018).

Beck U (1992) Risk Society: Towards a New Modernity. London: Sage.

Beck U (1999) World Risk Society, Malden, MA: Polity

Beck U (2013) Why "Class" is too Soft a Category to Capture the Explosiveness of Social Inequality at the Beginning of the 21st Century. British Journal of Sociology 64(1): $63-74$.

Botsman R (2017) Big data meets Big Brother as China moves to rate its citizens. Wired 21 Oct. Available at: http://www.wired.co.uk/article/chinese-government-social-creditscore-privacy-invasion (accessed 27 June 2018).

Bourdieu P (1984) Distinction: a Social Critique of the Judgement of Taste. Cambridge, MA.: Harvard University Press

Bourdieu P (1987) What Makes a Social Class? On the Theoretical and Practical Existence of Groups. Berkeley Journal of Sociology 32: 1-17.

Bourdieu P (2001 [1983]) The Forms of Capital. In Mark Granovetter and Richard Swedberg (eds) The Sociology of Economic Life, 2nd Edition, Westview Press, Boulder

Brauneis R and Goodman EP (2018) Algorithmic Transparency for the Smart City. Yale Journal of Law \& Technology 20(103): 103-176.

Bridle J (2018) New Dark Age: Technology and the End of the Future. London: Verso. 
Cardullo P and Kitchin R (2019) Smart urbanism and smart citizenship: The neoliberal logic of 'citizen-focused' smart cities in Europe. Environment and Planning C: Politics and Space 37(5): 813-30.

Catton WR and Dunlap RE (1978) Environmental sociology: A new paradigm. The American Sociologist 13(1): 41-9.

Chan T (2018) China's social credit system has blocked people from taking 11 million flights and 4 million train trips. Business Insider http://www.businessinsider.com/china-social-credit-system-blocked-people-takingflights-train-trips-2018-5 (accessed 10 July 2020).

Chakrabarty D (1992) Provincializing Europe: Postcoloniality and the critique of history. Cultural studies 6(3): 337-57.

Chen S (2017) China to build giant facial recognition database to identify any citizen within seconds. South China Morning Post. 12 Oct. https://www.scmp.com/news/china/society/article/2115094/china-build-giant-facialrecognition-database-identify-any (accessed 5 July 2019).

Chen Y and Cheung ASY (2017) The Transparent Self Under Big Data Profiling: Privacy and Chinese Legislation on the Social Credit System. https://papers.ssrn.com/sol3/papers.cfm?abstract id=2992537

Cheney-Lippold J (2017) We Are Data: Algorithms and the Making of Our Digital Selves. New York. NYU Press.

Chien SS and Woodworth MD (2018) China's urban speed machine: The politics of speed and time in a period of rapid urban growth. International Journal of Urban and Regional Research 42(4): 723-737. 
China Academy of Information and Communications Technology (2016) Comparative Study of Smart Cities in Europe and China 2014. Heidelberg: Springer.

Citron DK and Pasquale F (2014) The Scored Society: Due Process for Automated Predictions. Washington Law Review 89(1): 1-33.

Couldry N and Meijas N (2019) The Costs of Connection: How Data Is Colonizing Human Life and Appropriating It for Capitalism. Stanford, CA.: Stanford University Press.

Cowley R, and Caprotti F (2019) Smart city as anti-planning in the UK. Environment and Planning D: Society and Space 37(3): 428-448.

Curran D (2013) Risk Society and the Distribution of Bads: Theorizing Class in the Risk Society. British Journal of Sociology 64(1): 44-62.

Curran D (2015) Risk Illusion and Organized Irresponsibility in Contemporary Finance: Rethinking Class and Risk Society. Economy and Society 44(3): 392-417.

Curran D (2016) Risk, Power, and Inequality in the 21 $1^{\text {st }}$ Century. Basingstoke: Palgrave Macmillan.

Curran D (2018) Risk, Innovation, and Democracy in the Digital Economy. European Journal of Social Theory 21(2): 207-226.

Curran D (2018b) Environmental Justice meets Risk-Class: The Relational Distribution of Environmental Bads. Antipode 50(2): 298-318.

Dai X (2018) Toward a Reputation State: The Social Credit System Project of China. SSRN. 1-61. https://ssrn.com/abstract=3193577 
Dalton C, Clancy W, Fraser E and Thatcher J (2020) 'Smart' Discourses, the Limits of Representation, and New Regimes of Spatial Data. Annals of the American Association of Geographers 110(2): 485-96.

Datta A (2018) The digital turn in postcolonial urbanism: Smart citizenship in the making of India's 100 smart cities. Transactions of the Institute of British Geographers 43(3): 405-419.

Datta A and Odendaal N (2019) Smart cities and the banality of power. Environment and Planning D: Society and Space 37(3): 387-392.

Davis M (2001) Late Victorian Holocausts: El Niño Famines and the Making of the Third World. New York: Verso.

Economist (2018a) Public pushback. January 27: 36-7.

Economist (2018b) Chinese tech v. American tech. February 17: 61.

Economist (2018c) Financial inclusion. May 5: S1-12.

Economist (2018d) Apartheid with Chinese characteristics. June 2:19-22.

Economist (2018e) Walls have eyes. June 2: 4-6.

Economist (2020) China's built road. February 8: 1-12.

Eubanks V (2017) Automating Inequality: How High-Tech Tools Profile, Police, and Punish the Poor. New York: St. Martin's Press.

Fourcade M and Healy K (2013) Classification situations: Life-chances in the neoliberal era. Accounting, Organizations and Society 38(8): 559-572.

Fourcade M and Kluttz D (2020) A Maussian bargain: Accumulation by gift in the digital economy. Big Data \& Society. https://doi.org/10.1177/2053951719897092 
Gabrys J (2014) Programming environments: Environmentality and citizen sensing in the smart city. Environment and Planning D: Society and Space 32(1): 30-48.

Gardner N and Hespanhol L (2018) SMLXL: Scaling the smart city, from metropolis to individual. City, Culture and Society 12: 54-61

Green B (2019) The Smart Enough City: Putting Technology in Its Place to Reclaim Our Urban Future. Cambridge, MA: MIT Press.

Greenfield A (2013) Against the smart city. New York: Do Projects.

Gong YR (2016) Rental housing management as surveillance of Chinese rural migrants: the case of hillside compound in Dongguan. Housing Studies 31(8): 998-1018.

Haldane A, Brennan S, and Madouros V (2010) What is the Contribution of the Financial Sector: Miracle or Mirage? In A. Turner et al. The Future of Finance: The LSE Report. London School of Economics and Political Science.

Hainan Government Procurement Website (2018) Haikou shi chengshi danao 2018 nian shifan xiangmu gonggao [Public notice of Haikou City’s 2018 City Brain project]. Available at: http://ccgp-hainan.gov.cn/cgw/cgw show dylygg.jsp?id=1137 (accessed 1 October 2018).

Halpern O (2015) Beautiful Data. Durham: Duke.

Harvey D (1989) The Condition of Postmodernity. Oxford: Blackwell. Harvey D (2007) A Brief History of Neoliberalism. Oxford: Oxford University Press. He S, Li L, Zhang Y and Wang J (2018) A small entrepreneurial city in action. International Journal of Urban and Regional Research 42(4): 684-702.

Ho S (2018) Alibaba's investment in Malaysia is US\$100m and counting. The Edge Financial Daily, 19 June. Available at: 


\section{http://www.theedgemarkets.com/article/alibabas-investment-malaysia-us100m-and-}

counting (accessed 11 October 2018).

Horsley J (2018) China’s Orwellian Social Credit Score Isn’t Real. Foreign Policy.

November 16. https://foreignpolicy.com/2018/11/16/chinas-orwellian-social-creditscore-isnt-real/ (accessed 6 July 2019).

Hurley M and J Adebayo (2016) Credit Scoring in the Era of Big Data. Yale Journal of Law \& Technology 18(148): 148-216.

Just N and Latzer M (2017) Governance by algorithms: reality construction by algorithmic selection on the Internet. Media, Culture \& Society 39(2): 238-258.

Kitchin R (2014) The real-time city? Big data and smart urbanism. GeoJournal 79(1): 114.

Kitchin R (2016) The ethics of smart cities and urban science. Philosophical Transactions A, 374(2083): 1-15.

Krivý M (2018) Towards a critique of cybernetic urbanism: The smart city and the society of control. Planning Theory 17(1): 8-30.

Lapavitsas C (2009) Financialized Capitalism: Crisis and Financial Expropriation. Historical Materialism 17(2): 114-48.

Lapavitsas C (2013) Profiting without Producing: How Finance Exploits Us All, London: Verso.

Larson C (2018) China’s AI imperative. Science 359(6376): 628-630.

Lee KF (2018) AI superpowers: China, Silicon Valley, and the new world order. Houghton Mifflin Harcourt. 
Lin G and Zhang A (2015) Emerging spaces of neoliberal urbanism in China. Urban studies 52(15): $2774-2798$.

Mac Síthigh D and Siems M (2019) The Chinese social credit system: A model for other countries?. EUI Department of Law Research Paper 2019/01 (2019). https://cadmus.eui.eu/bitstream/handle/1814/60424/LAW_2019 01.pdf?sequence=1 $\underline{\text { \&isAllowed }=\mathrm{y}}$ (accessed 14 June 2019).

Marx K (1976) Capital Volume I. Harmondsworth: Penguin.

Marx K (1991) Capital, Vol 3. London: Penguin

Matsakis L (2019) How the West got China's social credit system wrong. Wired July 29. https://www.wired.com/story/china-social-credit-score-system/ (accessed 20 June 2019).

Mayer-Schoenberg V and Cukier K (2013) Big Data: A Revolution That Will Transform How We Live, Work, and Think. London: John Murray.

Mazzucato M (2018) The Value of Everything: Making and Taking in the Global Economy. London: Public Affairs.

McDonald T (2019) 'Social' money and working-class subjectivities: Digital money and migrant labour in Shenzhen, China. China Quarterly Epub ahead of print 19 August 2019. DOI: https://doi.org/10.1017/S0305741019001073.

Mohai P, Pellow D, and Roberts JT (2009) Environmental justice. Annual Review of Environment and Resources 34(1): 405-430.

O’Neill C (2016) Weapons of Math Destruction: How Big Data Increases Inequality and Threatens Democracy. New York: Penguin. 
Pasquale F (2015) The Black Box Society: The Secret Algorithms that Control Money and Information. Cambridge, MA: Harvard University Press.

People's Daily (2017) Chengshi danao kaiqi Hangzhou zhidu you “zhihui” [City Brain brings smart transportation to Hangzhou]. Xinhuanet. Available at: http://www.xinhuanet.com/itown/2017-03/08/c 136111348.htm (accessed July 25 2018).

Revell T (2017) China's super-smart city tracks your every move. New Scientist 3149: 7. Romero N (2018) China's Brain, Malaysia’s Pain. The Diplomat, 6 June. Available at: https://thediplomat.com/2018/06/chinas-brain-malaysias-pain/ (accessed 11 October 2018).

Sadowski J (2020) The Internet of Landlords: Digital Platforms and New Mechanisms of Rentier Capitalism. Antipode 1-19. Early Publish. https://doi.org/10.1111/anti.12595

Savage M, Warde A, and Devine F (2005) Capitals, Assets, and Resources: Some Critical Issues. British Journal of Sociology 56(1): 31-47.

Scott JC (1998) Seeing Like a State: How Certain Schemes to Improve the Human Condition Have Failed. New Haven, CT: Yale University Press.

Segal A (2018) When China rules the internet. Foreign Affairs September 2018. https://www.foreignaffairs.com/articles/china/2018-08-13/when-china-rulesweb? fa package=1122877. (accessed August 25, 2018).

Sennett R (2012) The stupefying smart city. LSECities. Available at: http://secities.net/media/objects/articles/the-stupefying-smart-city/en-gb/(accessed 3 July 2018) 
Sen AK (1993) Capability and Well-Being. In: Nussbaum M and Sen AK (eds) The Quality of Life. Oxford: Clarendon Press.

Sherman J (2013) Surviving the great recession: Growing need and the stigmatized safety net. Social Problems 60(4): 409-432.

Smart A (2018) Ethnographic perspectives on the mediation of informality between people and plans in urbanising China. Urban Studies 55 (7): 1477-1483.

Smart A and Curran D (in press) The prospects and social impact of big data-driven urban governance in China. In: Wu W and Gao Q (eds) China Urbanizing: Impacts and Transitions. New York: Columbia University Press.

Smart A and Smart J (2001) Local citizenship: welfare reform, urban/rural status, and exclusion in China. Environment and Planning A 33(10):1853-1869.

Solinger DJ (1999) Contesting Citizenship in Urban China: Peasant Migrants, the State, and the Logic of the Market. Berkeley: University of California Press.

Standing G (2011) The Precariat: The New Dangerous Class. London: Bloomsbury. Stiglitz J (2010) Freefall: Free Markets and the Sinking of the Global Economy, London: Allen Lane.

Tang A (2015) Questioning Smart Urbanism: Is Data-Driven Governance a Panacea? Chicago Policy Review November 2. Available at: http://chicagopolicyreview.org/2015/11/02/questioning-smart-urbanism-is-datadriven-governance-a-panacea/ (accessed 22 June 2018).

Tan-Mullins M et al. (2017) "Smart-eco cities in China: Trends and city profiles 2016." Exeter: University of Exeter (SMART-ECO Project) institutional design of (space for) experiments (eg smart city platforms). 
Townshend AM (2013) Smart Cities: Big Data, Civic Hackers, and the Quest for a New Utopia. New York: W.W. Norton.

Tufecki Z (2015) Algorithmic Harms Beyond Facebook and Google: Emergent Challenges of Computational Agency. Colo. Tech. LJ 13: 203-218.

Vanolo A (2014) Smartmentality: The smart city as disciplinary strategy. Urban Studies 51(5): 883-898.

Wacquant L (2008) Urban Outcasts: A Comparative Sociology of Advanced Marginality. Cambridge: Polity.

Weber M (1978) Economy and Society G. Wittich and C. Wittich (eds) Berkeley, CA: University of California Press.

Weber M (2002) The Protestant Ethic and the Spirit of Capitalism, London: Penguin.

Wu F (2018) Planning centrality, market instruments: Governing Chinese urban transformation under state entrepreneurialism. Urban Studies 55(7): 1383-1399.

Wu F (2020) Adding new narratives to the urban imagination: An introduction to 'New directions of urban studies in China. Urban Studies 57(3): 459-472.

Xue D and Wu F (2015) Failing entrepreneurial governance. Cities 43: 10-17.

Wisner B, Blaikie P, Cannon T, Davis I (2004) At Risk: Natural Hazards, People's Vulnerability and Disasters, Second Edition. London: Routledge.

Zhang S (2014) Land-centered urban politics in transitional China. Cities 41: 179-186. Zuboff S (2019) The age of surveillance capitalism. New York, NY: Public Affairs.

Notes 
${ }^{1}$ For recent discussion of how the emerging digital economy provides different opportunities for benefits and different risks, see Pasquale (2015), Mazzucato (2018), and Zuboff (2019). This paper aims to build on this literature of digital inequalities through the framing of risk-class, which analyses risks as objects of distribution, which can generate systematic 'risk positions'.

${ }^{2}$ More details and relevant news articles at

http:/www.scmp.com/news/china/society/article/2115094/china-build-giant-facialrecognition-database-identify-any (in English)

${ }^{3}$ Accessed at http://paper.ce.cn/jirb/html/2013-04/01/content 150302.htm (in Chinese)

${ }^{4}$ Accessed at http://society.people.com.cn/n1/2016/1024/c1008-28800857.html (in Chinese) 